\title{
Opinions and Viewpoints from Parents of Disabled Children
}

\author{
Arbana Zhapaj \\ University "Ismail Qemali" Vlorë \\ Email: arbanam2000@yahoo.com
}

\section{Doi:10.5901/jesr.2014.v4n6p546}

\begin{abstract}
This study is realized in Albania, aimed; promoting the development of a positive climate inside disabled children' families, which might be able to improve their capacities. Therefore, the paper is aimed at highlighting the specific needs of parents and of their disabled children, so that they might acknowledge and manage stress, as well as at presenting some prevention and intervention practices related to the difficulties encountered while growing a disabled child. The survey provides us with important data on how parents react to the first diagnosing of their child, how do they managed emotions, what is the impact of a disabled child in their family, what are the expectations and how is the collaboration with professionals working? The main purpose of the survey is to distinguish those aiding means, which families perceive as necessary. The answers shall serve as a joining bridge between professionals who deal with disabled children and their families.
\end{abstract}

Keywords: family, disabled children, partnership, emotions, professionals

\section{Introduction}

Parents dealing with disabled children in their families often face lack of information to fight reality, disdain and ignorance. However, they managed to overcome difficulties and return hope in their lives, by finding success for the future of these children in what seemed to be an inaccessible obstacle. By doing so they confirmed all the great effort to being humans.

If someone, some times ago had been able to give advice and hope to disabled people, these individuals and their families would not find it so hard to face such problems or would not experience such threshold of pain. We have been waiting so long that somebody makes something for this issue, but so far nothing has been done. Any research performed shows that disabled persons and their families need advice and support; however, few of them decide to go over this problem.

Many of the professionals, who are engaged in this field, still continue to hide their profession behind medical analyses.

There is little medical information and even less support to a new-born disabled child. Parents of these new-born disabled children ask for the aid of the practitioners, nurses, social assistants, who seem to be unprepared for dealing with the "misfortune" of such parents. In this way the long hours with medical assistance have just begun. Due to lack of information, parents keep waiting anxiously for the medical tests and the definition of diagnosis without receiving any accurate response.

Unintentionally, family problems grow out of everyday issues. Parents are filled with confusing and frightening emotions for their lovely disabled children and want to escape from their common life. What do they do?

And the war has just begun for a public school permit, with parents having to face inexplicable offences. They are anxious for the future of their children: will the school board allow them to enter a public school? What will happen when they grow up? Along with the sense of distance and frustration these parents increasingly doubt the future of their disabled children. Rejection is the feeling that mostly scares them, and the children use to get more frightened.

Parents' stress, anxiety, expectations and emotions are a good way to understand how they perceive the history of their life. Furthermore, their experiences stimulate professionals to give professional aid on the ways and methods of intervention. 


\subsection{Forms of social support and partnership to the development of disabled children}

Both parents and professionals fail to consider uncertainty as a positive adaptation motor, which can make them more creative in search of solutions. They are always anxious for meeting the preset goals. For this purpose, partnership strategies play a substantial role in reducing the anxiety of these parents and encouraging them to go safely through their own life.

What are the best conditions for creating partnership?

This partnership is built through reflection ON and IN the action within a relationship where power separates from knowledge, otherwise we would argue that $\mathrm{ON}$ is a technique that perfections thinking and reflection to create ideas to be implemented in real actions. IN is another efficient technique, which of course helps in building partnership, a place to share their experiences. This privileged context encourages mutual building of knowledge between each partner.

What is the outcome of these strategies?

The results confirm the efficiency of PRIFAM in favoring the best adaptation of parents to a more extended autonomy of the family. What is PRIFAM?

PRIFAM is an interdisciplinary intervention program built through the collaboration between parents and professionals. PRIFAM is a program that, thanks to its theoretical roots and the clinical model it adopts, has contributed to the restoration of parent-professional relations to the development of children with special needs. This collaboration is based on a clinical observation and it is an exchange of relations, knowledge and competences between both parties. The birth of a disabled child puts their family and especially their parents in a distressing process; however, with the aid of this program, which is aimed at building mutual relations between the concerned parties, this distressing process is transformed in a process of development, information, by learning to achieve this challenging goal, i.e. the adaptation of the parties to this process. Many professionals consider it a backpack carried by the child, which shall provide them with any necessary means throughout their own way.

PRIFAM presents the following multisided effects:

The individual aspect:

- less emotional distress, anxiety and depression

- The more mothers are confident in their resources, the more they will perceive this situation as a new challenge.

The marital aspect

- very good tacit support and tasks sharing

- involvement of father since the first day of birth may help in maintaining family harmony.

The parental aspect

- a greater sense of competence related to taking care of the disabled child

- less parental stress

- a more positive and constructive behavior and perception of the child's disability as well as of their parental situation.

- less diminution of their role as parents

The intrapersonal aspect

- more confidence in the support that others may give to them

\subsection{Counseling and its effects}

Counseling is a professional intervention, which employs the technique of colloquy (conversation) and some strategies of communication to help professionals find the most appropriate way to decision making either for themselves or for their clients. It helps both parties face complex situation and look for the best possible solutions.

The presence of a child with special needs puts them and their families in various complex situations, where they have to communicate in different social and medical systems. It is precisely in such situations that counseling becomes important: the professional offers an empathic and unbiased support by becoming a stimulus either for the children with special needs or for their families to help them gain self-confidence and find necessary and useful solutions. A counselor deals precisely with aiding professionals or the work team change and control their communication methods with the patient. Thanks to these strategies they must built a collaboration spirit between them and the family of the person with special needs. The use of such interventions for the sake of collaboration with the concerned families and of other systems aimed at creating individual relations is called indirect counseling, which helps improve the communication flux 
within the work group.

\section{Methodology}

\subsection{Participants}

Participants in this research work are parents of disabled children $(n=80)$. Participants gave their opinions by answering to a questionnaire, which was later examined by the scholar. Care was taken that both genders were included in the research work. The geographical distribution of the questionnaires corresponded to the city of Vlora and Fier. The participants were elected randomly in collaboration with the community service centers and the special schools of the respective areas.

\subsection{Tools and Materials}

Information data were provided by the questionnaire. The questionnaire completed by the family members of the disabled children contained a column with demographic data and 11 closed questions, where the participants checked the most appropriate option for their own situation. Finally, they had to answer an open question on what they thought would be the best way to improve the situation. The questionnaire was taken from "

\subsection{The procedure}

For the collection of the relevant data we had to administer the questionnaires of a single period. The period for the collection of the relevant data is January through May 2014. Such a long extension was due to the great difficulties encountered with the concerned parents.

\subsection{Statistical Analysis}

The data collected through quantitative questionnaires were first entered and then processed statistically. Since most of the variables were nominal and ordinal, percentages and frequency were analyzed. For the analysis of the data provided by the opened questions, qualitative methods of analysis were employed.

\subsection{Ethics while performing the study}

The decision to be included in the research work was made personally by the concerned individuals. They were informed on the freedom of will to participate or not in this research work. The heading of any questionnaire contains clear information on the purpose of this research work and the way it should be completed. The principle of anonymity and confidentiality were properly applied during all the phases of this research work.

\section{Data analysis and Discussion}

This research work was aimed at providing the audience with some useful conclusions on the relations created between the parents of the disabled children and the professionals who work with such children as well as on the marital and community relations.

The selected sample is composed of 80 individuals, with 33 mothers and 33 fathers, and 14 single moms. The focus of this research work is answering to some questionnaires with the purpose of evidencing the marital relations between parents of disabled children, their confidence in professionals and their expectations with regard to the performance of their children.

All these variables relate to such factors as the educational, social and economic level of the parents.

We must point out that the data contained in this questionnaire are taken from a severe social context with regard to disability assessment. This is quite obvious from the words of the concerned parents, who relate the problem considerably to the backward mentality and prejudice that characterize the Albanian society. From a general viewpoint, without mentioning accurate figures, we note that parents and professionals have the same fear: they both have the fear of perceiving incompetence in the person they are facing. 
As we have already mentioned, the Albanian context finds it really hard to accept and perceive disability since the first moment of its notification. Another problematic issue related to the Albanian system and citizens involved in the study is lack of information available to parents in relation to the disability of their children.

Such lack of information is for two reasons: first, these parents enclose themselves inside certain walls of solitude and create no relation with the outside world and second, often professionals encounter difficulties due to parents lacking confidence in their service.

Graph. 1. Who gave you the news on your child's disability?

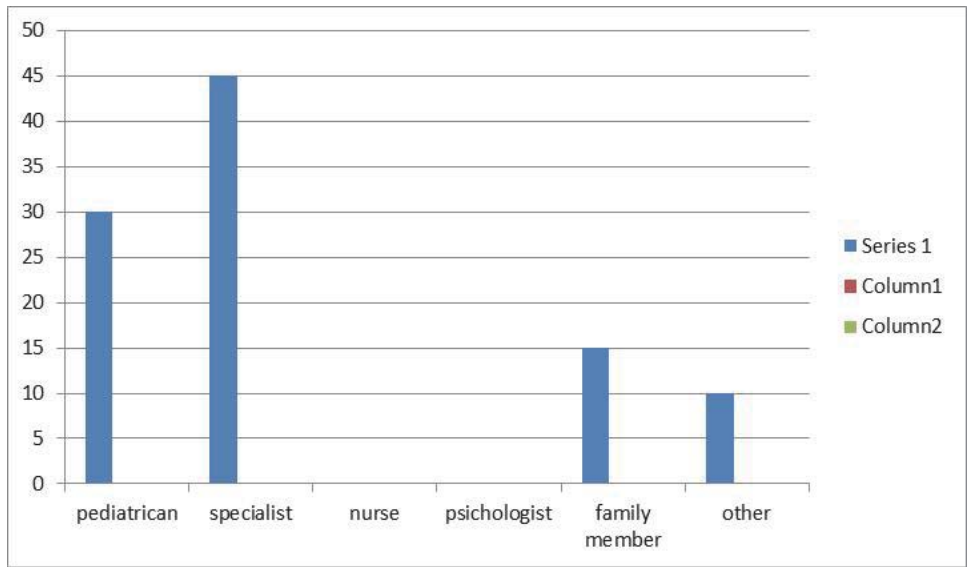

Source: Data elaborated by the author from questionnaire

It is obvious that parents were informed by two types of professionals, i.e. the specialist and the pediatrician on the disability of their child. In most cases, $45 \%$ of the informants are specialists, i.e. professionals we deal with the assessment of disabled persons in specialized centers, whereas $30 \%$ of the informants are pediatricians. Other informants are family members, educators or teachers. In consideration of the introduced cases, neither nurses nor psychologists are informants.

Graph. 2. What do you think it is important with regard to communication?



Source: Data elaborated by the author from questionnaire 
With regard to the parents' community, we think that it might be important to display a detailed information: $45 \%$ of these parents have considered the data provided by the professional on their children disability; $35 \%$ have been worried about the future of their children; $18 \%$ have asked for psychological assistance, whereas $2 \%$ of these parents have failed to specify what kind of help would best serve to their situation.

- How does the way of perceiving notification on a disabled child relate to the educational, economical ad social level of the concerned parents?

With regard to how parents of different educational, economical and social level react toward the first notification on their children disability, the data provided in the survey show the following results: both fathers and mothers perceive feelings of anxiety, stress and depression; however the extent of such feelings is greatly determined by their educational, economical and social level: the higher the educational level, the lower the feeling of anxiety and stress perceived.

$65 \%$ of the interviewed had completed the upper secondary education, whereas $35 \%$ had finished university and middle school.

Graph. 3. Which of the following emotions have you perceived most?

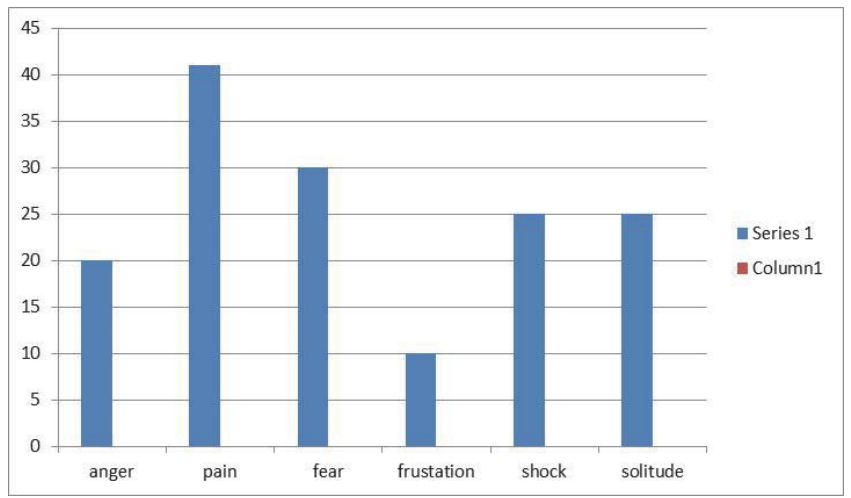

Source: Data elaborated by the author from questionnaire

With regard to the above emotions, pain is what parents perceive most. Compared to other studies, parents have almost the same perceptions. The data provided in the study of J.M. Bouchard from Canada are similar to those provided in this study as far as parents' reaction and emotions are concerned. Parents reveal that they perceive insecurity of professionals and practitioners as if they were hiding the truth, which adds up to the insecurity of parents themselves about the future of their children. This insecurity is translated into fear of parents from the new situation created in their family and concern about how they will manage such situation.

Graph. 4. Who makes decision about your child?

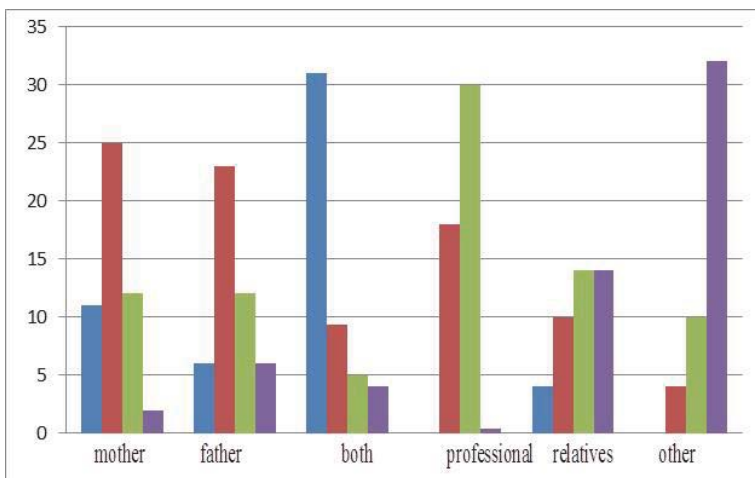

Source: Data elaborated by the author from questionnaire 
In most cases, a great part of the decisions is made by mothers, whereas few of them are made by fathers; however all decisions are very likely to be made by both parents. On the other hand, professionals make some decisions, which - as parents state - refer to the level of disability and medical assistance.

Graph. 5. What of the following properties characterizes you as a parent?

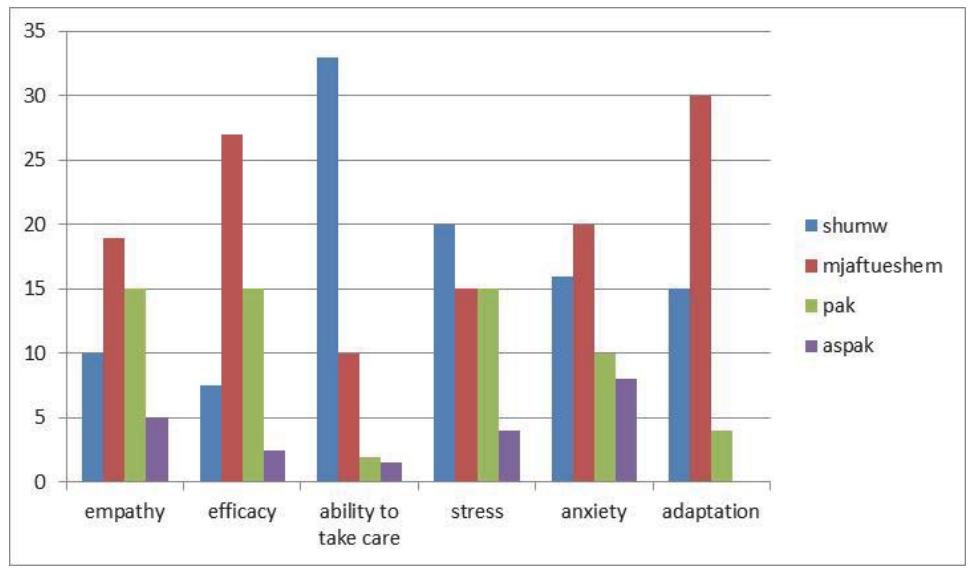

Source: Data elaborated by the author from questionnaire

As the diagram shows, parents are characterized - to a great extent - by their ability to take care, which exceeds their ability to adapt to the new situation.

Graph. 6. What impact your child's disability has in the following relations?



Source: Data elaborated by the author from questionnaire

Stress level, economical situation and family relation are the most influenced relations by a child's disability; however it has a certain impact in all relations.

- The impact of disability in partnership relations

The data provided in the study show gender differences referring to the way of perception. $65 \%$ of fathers state 
that their children disability and the time their partners dedicate to the disabled children have created a gap in their partnership relations. $56 \%$ say that there has been no change in their perception of partnership relations, which means that their children disability has had no impact.

Graph. 7: What do you expect from your disabled child?

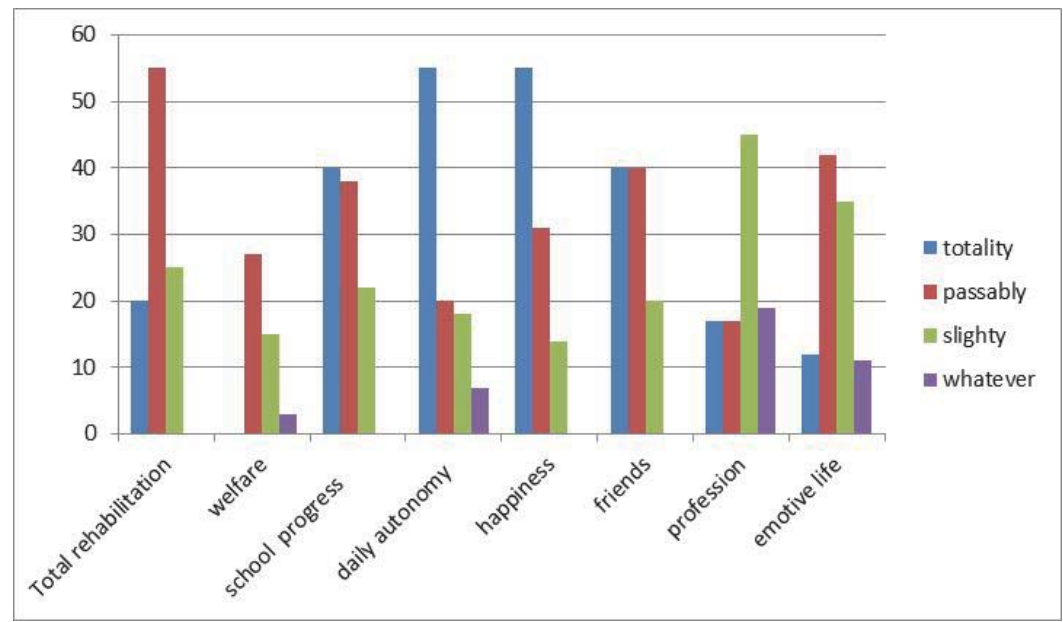

Source: Data elaborated by the author from questionnaire

Welfare, daily autonomy and happiness are main expectations of parents for their disabled children. What parents expect less from their children are rehabilitation, friendship, profession, school progress and emotive life. Referring to confidence in child's progress, almost $73 \%$ of mothers and $57 \%$ of fathers were optimistic and had high expectations for their child progress.

Graph 8. Who did you trust most in critical moments of your life?

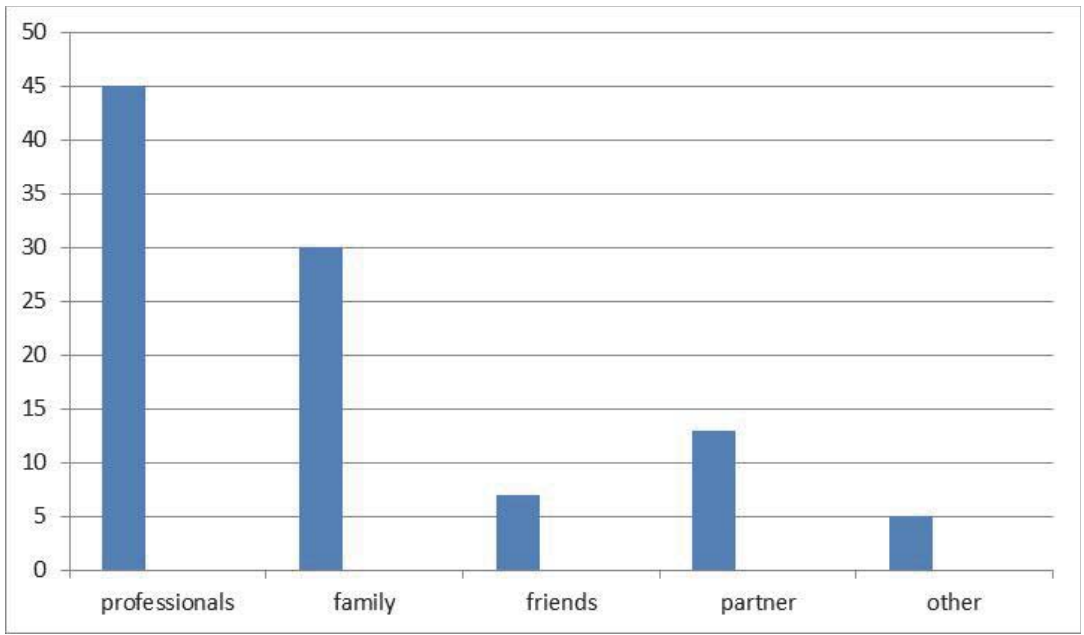

Source: Data elaborated by the author from questionnaire 
It is obvious that in critical moments of their life parents have been confident in professionals. As parents state, the main reason why they trust in professionals, is because they have already done what they could and didn't know how to proceed further; another reason is because they have seen their children progress while working with professionals, or because these professionals were recommended by friends.

Graph 9. In what moment of your life did you ask for the support of a professional?

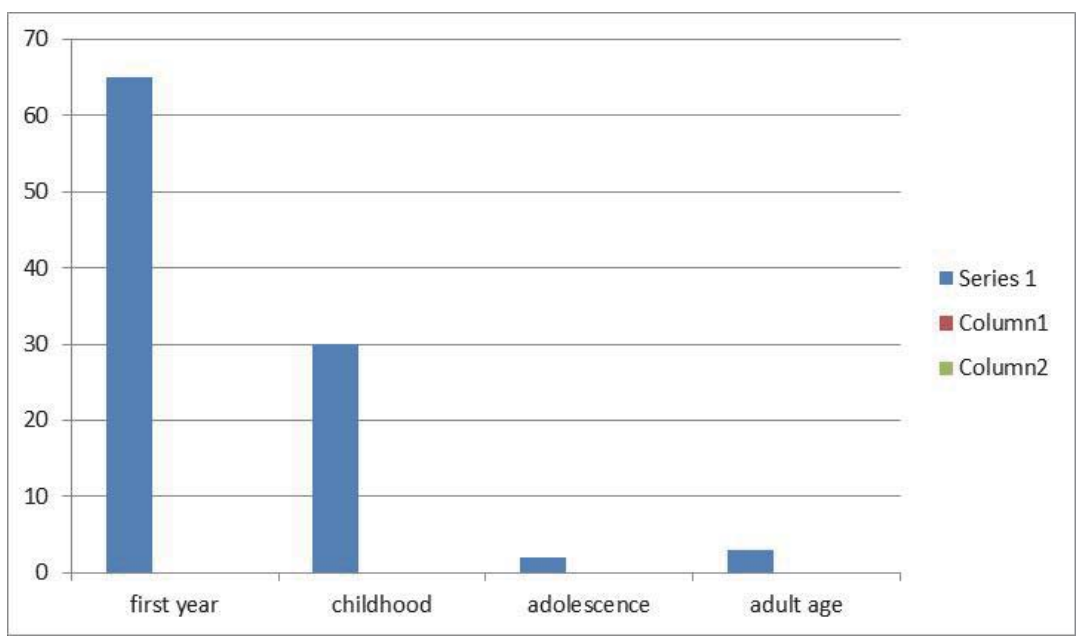

Source: Data elaborated by the author from questionnaire

Graph 10. Has your family received assistance other than professional?

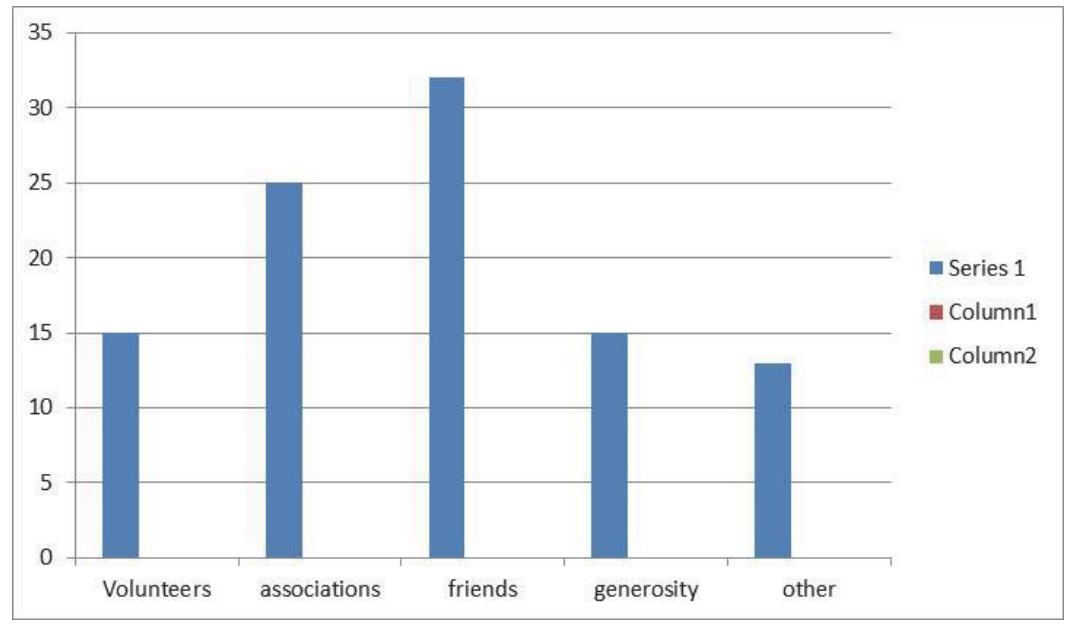

Source: Data elaborated by the author from questionnaire

As one may notice, these families have been assisted by friends, who have supplied them with financial means and have taken care about the disabled children; associations have largely offered their services, whereas generous individuals have assisted these families financially. Institutions like school, municipality, commune, centers have also supported these families. 


\section{Conclusions}

Human development model introduced by Bronfenbrenner (1979) describes how individuals develop gradually by communicating with the surrounding environment and how they influence this surrounding environment. Ecosystem is defined as a group of interdependent structures and ecosystem approach focuses on the interconnection between multiple elements of these systems and their impact. It also allows the study of a problem in its plurality by considering the various contexts (interpersonal, social and physical) and the dynamics by which the developmental process takes place. It highlights the importance of quality interactions between elements of the situation.

After all we have tried to give a general image of how parents of disabled children express their emotions, opportunities, priorities, needs and goals.

According to principles, ethics and duties of the professionals who deal with disability cases, in order for these disabled children and their parents to actively participate in building a system that represents not only physical but mostly human interconnections, they should:

know, explain, formulate, define and respond to:

1. opportunities

2. goals

3. priorities

4. needs

5. emotions

\section{References}

Aldegani D. e Baratto L. 2000, Anche Alvise è cresciuto, Edizioni Del Cerro, Livorno.

Arbana Zhapaj. Shtepia Botuese, Ymeraj, Fier 2013 "Mbi Aftesine e Kufizuar".

Arbana Zhapaj. Shtepia Botuese, Kristal , Tirane2011 "Pedagogjia e Specializuar"

Bailey K.D. 1995, Metodi della ricerca sociale, II Mulino, Bologna.

Bandura A., 2000, Autoefficacia. Teoria e applicazioni, Edizioni Erickson, Trento.

Berkman L.F., Syme S.L. 1979, Social Networks, Host Resistance, and Mortality: A Nine-Year Follow-Up Study of Alameda County Residents, in American Journal of Epidemiology, n. 109.

Bezze M., Faenzi G., Lippi L., Paganelli L., Pompei A. e Vecchiato T. 2005, La classificazione dei servizi e degli interventi sociali, in Studi Zancan, n. 2.

Bouchard J.M, 2002, Partenariat et agir de communication, in Guerdan, V., Bouchard, J-M., Mercier, M., 2002, Partenariat, chercheurs, praticiens, familles, Montréal, Les Éditions Logiques.

Bronfenbrenner, U. 1986, Ecologia dello sviluppo umano, Bologna, il Mulino.

Brown, R.I., Bayer, M.B., MacFarlane, C. 1989, Rehabilitation Programmes: Performance and Quality of Life of Adults with Developmental Handicaps, Lugus, Toronto.

Canali C., Maluccio A., Vecchiato T. (a cura di), 2003, La valutazione di efficacia nei servizi alle persone, Fondazione Zancan, Padova.

Canevaro A. 2000, La relazione d'aiuto: aspetti metodologici e obiettivi educativi, in 'Studium Educationis',n. 4.

Cornao S. 2000, I focus group, Franco Angeli, Milano.

Cyrulnik B. 2000, II dolore meraviglioso, Frassinelli, Milano.

Dall'Aglio E. 1994 Handicap e famiglia, in AA.VV., Quaderni di psicoterapia infantile, n. 29.

David J., Delvin E., Le Polain De Waroux P. 1991, Una vita possibile. Handicap mentale e famiglia, SEI, Torino.

Desmet H., Pourtois J.P., 2005 Culture et bientraitance, De Boeck, Bruxelles.

Elias N. 1990, La società degli individui, II Mulino, Bologna.

Falcon G. 2002 Lineamenti di diritto pubblico, Cedam, Padova.

Fava G. (a cura di) 1996, Cosa si è scritto, in 'Haccaparlante' n. 49.

Gargiulo R. 1987, Lavorare con i genitori di bambini handicappati, Zanichelli, Bologna.

Garmezy N. 1996, Reflections and commentary on risk, resilience, and development,in R. Haggerty, L. R. Sherrod,

N. Garmezy, \& M. Rutter Eds., Stress, risk, and resilience in children and adolescents: Processes, mechanisms, and interventions, University Press, -Cambridge.

Gioga G., Sartori P. (a cura di) 2005, Percorsi innovativi per l'inserimento lavorativo, Cleup, Padova.

Goode, D.A. (Ed.) 1994, Quality of Life for Persons with Disabilities: International Perspectives and Issues, Brookline, Cambridge

Groppi T., Rossi E., Tarchi R. 2002, Idee e proposte per il nuovo statuto della Toscana. Atti del Seminario Pisa, 14 giugno 2001

Hanau C., Mariani Cerati D. 2003, II nostro autismo quotidiano. Storie di genitori e figli, Erickson, Trento.

L'Écuyer R. 1990. Méthodologie de l'analyse développementale de contenu., Les Presses de l'Université du Québec, Montréal, Québec.

Losito G. 1996, L'analisi del contenuto nella ricerca sociale, Franco Angeli, Milano.

Kaufmann J.C. 1996, L'entretien compréhensif, Nathan, Paris. 
Kubler-Ross 1998, La morte e il morire, tr.it. Cittadella, Assisi.

Maye R., Ouellet F., Saint-Jacques A., Turcotte et coll. éds, Méthodes de recherche en intervention sociale, Gaëtan Morin, MontréalParis.

Malaguti E., 2005, Educarsi alla resilienza. Come affrontare crisi e difficoltà e migliorarsi, Erickson, Trento.

Mantovani S. (a cura di) 1998, La ricerca sul campo in educazione, Mondadori, Milano.

Mariazzi S. 2001, L'insorgere del trauma, in "Famiglia Oggi", n. 5.

Meazzini P., 1997, Handicap-passi verso l'autonomia, Giunti Gruppo Editoriale, Firenze.

Milani P., Qualità della vita e qualità dell'integrazione: la risorsa famiglia, in lanes D., Tortello M. a cura di, La Qualità dell' integrazione scolastica. Disabilità, disturbi dell'apprendimento e differenze individuali, Erickson, Trento, 1999.

Milani P. (a cura di) 2001, Manuale di Educazione Familiare Ricerca, intervento, formazione, Erickson

Morrone A. 2003, La Corte Costituzionale riscrive il Titolo V, in Quaderni Costituzionali, n. 4

Pelchat D., Bouchard J.-M. e Lefebvre H. 2001, Progetto d'intervento familiare sistemico e precoce rivolto a genitori di neonati con deficit e i suoi effetti longitudinali sull'adattamento della famiglia, in Milani P. (a cura di), Manuale di educazione familiare. Ricerca, intervento, formazione, Erickson, Trento.

Pelchat D., Lefebvre H. 2005, Apprendre ensemble. Le PRIFAM, Programme d'Intervention interdisciplinaire et familiale, Chenelière Education, Montréal 